\title{
Factors Regulating Astringency of Whey Protein Beverages
}

\author{
J. W. Beecher, ${ }^{*}$ M. A. Drake, $†$ P. J. Luck, $†$ and E. A. Foegeding ${ }^{1}$ \\ ${ }^{*}$ Campbell Soup Company, Camden, NJ 08103 \\ †Department of Food, Bioprocessing, and Nutrition Sciences, North Carolina State University, Raleigh 27695
}

\begin{abstract}
A rapidly growing area of whey protein use is in beverages. There are 2 types of whey protein-containing beverages: those at neutral $\mathrm{pH}$ and those at low $\mathrm{pH}$. Astringency is very pronounced at low $\mathrm{pH}$. Astringency is thought to be caused by compounds in foods that bind with and precipitate salivary proteins; however, the mechanism of astringency of whey proteins is not understood. The effect of viscosity and $\mathrm{pH}$ on the astringency of a model beverage containing whey protein isolate was investigated. Trained sensory panelists $(\mathrm{n}=$ 8) evaluated the viscosity and $\mathrm{pH}$ effects on astringency and basic tastes of whey protein beverages containing $6 \% \mathrm{wt} / \mathrm{vol}$ protein. Unlike what has been shown for alum and polyphenols, increasing viscosity (1.6 to 7.7 $\mathrm{mPa} \cdot \mathrm{s}$ ) did not decrease the perception of astringency. In contrast, the $\mathrm{pH}$ of the whey protein solution had a major effect on astringency. A pH 6.8 whey protein beverage had a maximum astringency intensity of 1.2 (15-point scale), whereas that of a $\mathrm{pH} 3.4$ beverage was 8.8 (15-point scale). Astringency decreased between $\mathrm{pH}$ 3.4 and 2.6, coinciding with an increase in sourness. Decreases in astringency corresponded to decreases in protein aggregation as observed by turbidity. We propose that astringency is related to interactions between positively charged whey proteins and negatively charged saliva proteins. As the $\mathrm{pH}$ decreased between 3.4 and 2.6, the negative charge on the saliva proteins decreased, causing the interactions with whey proteins to decrease.
\end{abstract}

Key words: astringency, saliva, whey protein

\section{INTRODUCTION}

Whey protein-containing beverages are designed to be attractive to a variety of markets because of the highquality proteins they provide. The style of beverages containing whey proteins can be controlled by $\mathrm{pH}$. Beverages produced at near neutral $\mathrm{pH}(\mathrm{pH} \sim 6.8)$ are gener-

Received February 6, 2008.

Accepted March 12, 2008.

${ }^{1}$ Corresponding author: allen_foegeding@ncsu.edu ally opaque and available in such flavors as chocolate, orange cream, and vanilla. Acidic beverages $(\mathrm{pH}<3.5)$ are relatively clear and available in fruity flavors such as grape, lemon-lime, and fruit punch. Whey proteins must remain dispersed and soluble in order for the beverages to retain their clarity. Whey protein ingredients tend to be least soluble at their isoelectric point ( $\mathrm{pH} \sim 5.2$ ) (Phillips et al., 1994), and solubility increases as pH is decreased (Pelegrine and Gasparetto, 2005). Low $\mathrm{pH}$ not only allows for clarity in the beverages, but also has important thermal processing and storage implications.

There is a concern related to flavor attributed to a high level of astringency in beverages containing whey proteins at higher protein concentrations $(>3 \%)$ and at low $\mathrm{pH}$ (Sano et al., 2005). Because flavor is an important factor affecting consumer liking of foods and beverages, high levels of astringency will limit acceptance. Astringency of polyphenols and tannins has been extensively studied (Guinard et al., 1986; Vivas and Glories, 1996); however, very little work has investigated protein astringency. With the demand for proteinfortified foods and beverages increasing steadily, controlling astringency to improve overall flavor is important.

Astringency is associated with red wine and many other foods and beverages including tea (Scharbert et al., 2004) and whey proteins (Sano et al., 2005). It is generally attributed to specific compounds, such as alum (Peleg et al., 1998), polyphenols (Lesschaeve and Noble, 2005), and acids (Lawless et al., 1996). A model for the perception of astringency describes the complexation and precipitation of the astringent compounds with salivary proline-rich proteins (PRP), which increase friction in the mouth, perceived as astringency (Jobstl et al., 2004). Lee and Lawless (1991) describe astringency as a complex group of sensations involving dryness, roughness of oral surfaces, and tightening, drawing, or puckering of the mucosa and muscles around the mouth. Although astringency is considered a tactile sensation (Green, 1993) rather than a basic taste, it is clearly a critical component of overall flavor (Lawless and Heymann, 1998). 
The mechanism of whey protein astringency is not fully understood. Sano et al. (2005) showed that whey protein isolate was more astringent at $\mathrm{pH} 3.5$ than gelatin. They attributed this difference to whey proteins being more positively charged at $\mathrm{pH} 3.5$ than gelatin. Moreover, they suggested that astringency was due to whey proteins $(\mathrm{pH} 3.5)$ mixing with saliva $(\mathrm{pH}$ 7.0) to form a $\mathrm{pH} 5.0$ solution in which whey proteins precipitate, causing astringency. Saliva proteins, essential to the polyphenol-based astringency mechanism, were not mentioned in the whey protein astringency mechanism of Sano et al. (2005). Other positively charged polymers have been shown to cause astringency. Chitosan exhibits astringency when dissolved in an acidic solution when it is positively charged due to protonated amine groups (Rodriguez et al., 2003). Astringency increased with a decrease in $\mathrm{pH}$ ( $\mathrm{pH} 6.7$ to 3.9), coinciding with an increase in turbidity of saliva-chitosan mixtures. This suggests that molecular interactions between the positively charged chitosan and salivary proteins are involved in astringency (Rodriguez et al., 2003). Therefore, rather than precipitation of whey proteins due to $\mathrm{pH}$ changes, astringency of whey proteins could be related to interactions with PRP, like what has been shown for polyphenol compounds.

It would be desirable to develop ways to decrease astringency in whey protein beverages. Tannin and alum-based astringency is associated with fluid viscosity. Increasing viscosity of grape seed tannin solutions (from $\sim 1$ to $8 \mathrm{mPa} \cdot \mathrm{s}$ ) with carboxymethylcellulose decreases maximum astringency (Smith et al., 1996). Likewise, a significant decrease in astringency in the viscosity range of $\sim 1$ to $8 \mathrm{mPa} \cdot \mathrm{s}$ is seen in alum solutions thickened with methylcellulose (Smith and Noble, 1998).

The objectives of this study were 2-fold. First, the effects of viscosity on whey protein-based astringency were examined to determine if, as observed with tannins and alum, this would reduce astringency. Second, the effect of $\mathrm{pH}$ on astringency was examined.

\section{MATERIALS AND METHODS}

\section{Beverage Preparation}

The model beverage formulation contained whey protein isolate (BiPro, Davisco Foods, International, Le Sueur, MN; 91.97\% protein), phosphoric acid (Mallinckrodt, Hazelwood, $\mathrm{MO}$ ) for lowering $\mathrm{pH}$, and sucralose (McNeil Nutritionals LLC, Fort Washington, PA) to impart sweetness. Beverages varying in viscosity contained maltodextrin at $0,10,15$, and $20 \% \mathrm{wt} / \mathrm{vol}$ (M100, National Starch Food Innovation, Bridgewater, NJ) or $0.27 \% \mathrm{wt} / \mathrm{vol}$ methylcellulose (TIC Gums, Belcamp, MD) as thickeners.
Beverages were prepared to contain $6 \%$ protein wt/vol whey protein isolate. Protein powders and thickeners, when used, were hydrated in deionized water by mixing for $2 \mathrm{~h}$ at approximately $70 \%$ of the final volume. In the viscosity-effect experiment, beverages containing thickeners were adjusted to $\mathrm{pH} 3.4$ using $2 \mathrm{~N} \mathrm{H}_{3} \mathrm{PO}_{4}$, and brought to volume with deionized water. A noprotein beverage was prepared as a control, using $2 \mathrm{~N}$ $\mathrm{H}_{3} \mathrm{PO}_{4}$ to adjust $\mathrm{pH}$ to 3.4 . In the $\mathrm{pH}$-effect experiment, samples (starting $\mathrm{pH}$ was 6.8 ) were prepared by adjusting to a final $\mathrm{pH}$ of 2.6, 3.0, and 3.4 with $2 \mathrm{~N} \mathrm{H}_{3} \mathrm{PO}_{4}$. A no-protein solution with the same buffering capacity (as determined by titrating a 6\% protein, $\mathrm{pH} 3.4$ solution with $2 \mathrm{~N} \mathrm{NaOH}$ ) as the $\mathrm{pH} 3.4$ whey protein beverage was prepared by adjusting $0.2 \mathrm{~N} \mathrm{H}_{3} \mathrm{PO}_{4}$ to $\mathrm{pH} 3.4$ with $2 \mathrm{~N} \mathrm{NaOH}$.

Sweetness was controlled by adding $0.017 \% \mathrm{wt} / \mathrm{wt}$ sucralose (a sweetness similar to $10 \% \mathrm{wt} / \mathrm{vol}$ sucrose). Sucralose concentration was decreased in beverages containing maltodextrin assuming sucralose and maltodextrin were $600 \times$ and $10 \%$ as sweet as sucrose (Grenby, 1991). Beverages (300 mL) were poured into 500-mL media jars (Fisher Scientific, Pittsburgh, PA) and immersed in a $90^{\circ} \mathrm{C}$ water bath (PolyScience Microprocessor Controlled Water Bath, Niles, IL) for $15 \mathrm{~min}$ with a dual action shaker set at $30 \mathrm{rpm}$. After heating, beverages were brought to $4^{\circ} \mathrm{C}$ in less than $30 \mathrm{~min}$ by immersing the jars in crushed ice. Beverages were held at $4 \pm 1^{\circ} \mathrm{C}$ until used.

\section{Sensory Analysis}

Subjects. Eight healthy subjects (6 female and 2 male, ages 23 to 53) were selected for the study based upon their interest and availability. All subjects were students or faculty in the NC State Department of Food Science.

Training. Sensory analysis was conducted in compliance with the NC State University institutional review board human subject regulations. Panelists were trained to evaluate sweet, sour, bitter, and astringency using the Spectrum intensity scale (Meilgaard et al., 1999b). Basic tastes (sweet, sour, and bitter) and astringency training and evaluation sessions were kept separate throughout the study. Panelists were trained for $10 \mathrm{~h}$ (twenty 30-min sessions) to evaluate sweet, sour, and bitter tastes and $20 \mathrm{~h}$ (forty 30-min sessions) to evaluate astringency. Training lasted for 5 mo. Sucrose (purchased at a local grocery store), citric acid (Tate and Lyle plc, London, UK), and caffeine (Sigma-Aldrich, St. Louis, MO) were used for sweet, sour, and bitter reference solutions respectively. Alum (McCormick, Hunt Valley, MD) was used as an astringent reference. 
On the first day of training, subjects were familiarized with sweet, sour, and bitter tastes by tasting $5 \%$ sucrose (sweet 5), $0.08 \%$ citric acid (sour 5), and $0.05 \%$ caffeine (bitter 2) solutions. After the first day of training, between 7 and 10 samples of known intensities (0 to 15 Spectrum intensity scale) were presented to panelists at each training session in $60-\mathrm{mL}$ plastic cups randomly numbered with 3 -digit codes. Forty milliliters of the following reference solutions were provided to all panelists at all sessions: sour $2(0.05 \%$ citric acid), sour $5(0.08 \%$ citric acid), sweet 8 (8\% sucrose), sweet 12 (12\% sucrose), and bitter 2 (0.05\% caffeine; Meilgaard et al., 1999a). Samples and references were stored at $4 \pm 1^{\circ} \mathrm{C}$ and tempered to room temperature $2 \mathrm{~h}$ before evaluation. During the first 12 training sessions, panelists indicated the maximum intensities for each sample using a 15-point scale labeled none at number 0 on the left, and very strong at number 15 on the right. Ballots were collected and monitored for panelist accuracy and consistency.

After 12 training sessions, panelists were trained to use computerized data entry in place of paper ballots in sensory booths (Compusense 5 v4.6, Compusense Inc., Guelph, Ontario, Canada). All 3 attributes were scored on a 15-point category scale exactly as was done during training. When samples of known intensities were evaluated, feedback was provided to the panelists for training and calibration purposes. Whey protein model beverages were also evaluated during the last 8 training sessions.

On the first day of astringency training, astringency was defined for the subjects as "the complex of sensations due to the shrinking, drawing, or puckering of the epithelium as a result of exposure to substances such as alums or tannins" (ASTM, 1989). Alum solutions of astringent intensities $2(0.02 \%$ alum $)$ and $10(0.1 \%$ alum) were provided to panelists as examples of low and high intensities of astringency. Tea (6 Lipton tea bags added to $1 \mathrm{~L}$ of boiling, deionized water and steeped at ambient temp for $30 \mathrm{~min}$ ) was also provided as an example.

Between 3 and 4 samples of known intensities of alum were presented to panelists at each training session. Panelists were instructed to take the entire sample (20 $\mathrm{mL} \pm 0.1 \mathrm{~mL}$ ) into their mouth and swish for $5 \mathrm{~s}$ before expectorating. After expectorating, maximum astringent intensity was noted on paper ballots using 15-point category scales as described above. A rinse protocol was established for astringency evaluation to minimize carryover effects. After maximum intensity was reached and recorded, panelists rinsed with carboxymethylcellulose (CMC, Type 7MF, $5.5 \mathrm{~g} / \mathrm{L}$, Hercules-Aqualon, Wilmington, DE), sipped deionized water, ate a piece of unsalted cracker, and sipped water again (Brannan et al., 2001a; Colonna et al., 2004). Panelists waited 2 min between samples. During training, alum references were provided.

After 22 training sessions, panelists switched to using computerized data entry (Compusense 5 v4.6, Compusense Inc.) in booths. Panelists were introduced to the time-intensity module in Compusense, and 8 training sessions were conducted before the real evaluation. During this training, 3 unknown samples were evaluated by each panelist at each session. Panelists took the entire sample in their mouths while clicking the start button in the time-intensity module. They swished the sample in their mouths and expectorated at $5 \mathrm{~s}$, indicated by the clock on the computer screen. Intensity values were recorded automatically at 2 -s intervals while panelists moved the mouse along a horizontal category scale numbered 0 to 15 for up to $3 \mathrm{~min}$. Values determined from time-intensity curves were: maximum intensity (IMAX, relative units), time to maximum intensity (s), total duration of astringency ( $\mathrm{s}$ ) and area under the time-intensity curve (relative units).

Evaluation. Formal evaluations of basic tastes took place in booths with samples at room temperature. A sweet and sour warm up (5\% sucrose, $0.1 \%$ citric acid) was tasted first, followed by all 6 unknown samples. Sweet, sour, and bitter attributes were rated for all samples. Four replications were performed. Panelists were provided with unsalted crackers and deionized water to cleanse the palate between samples.

Immediately before beginning each session of astringency analysis, panelists swished an alum solution $(0.06 \%$ alum $)$ for $5 \mathrm{~s}$ before expectorating. This sample was not evaluated. Rather than provide references for panelists to taste during evaluation, an alum solution $(0.08 \%$, astringency intensity $=8)$ was evaluated first as a warm-up sample. Samples were evaluated using the Compusense time-intensity module as described previously. No more than 3 samples were evaluated in any given session to minimize build-up of astringency. The CMC rinse protocol and a forced 3-min break were required between all samples. Orders of presentation were balanced for first-order carryover effects using Williams Latin squares (Schlich, 1993). Eight sessions (4 replications) were performed.

\section{Viscosity Measurement}

Shear rate sweeps were performed in a StressTech Rheometer (Rheological Instruments AB, Lund, Sweden) with a smooth cup and bob to evaluate sample viscosities. All viscosities were measured at $20^{\circ} \mathrm{C}$ between shear rates 10 and $100 \mathrm{~s}^{-1}$. Samples were presheared at $50 \mathrm{~s}^{-1}$ for $60 \mathrm{~s}$ and allowed to equilibrate for $20 \mathrm{~s}$ before measurement. A delay time of $10 \mathrm{~s}$ and an 
integration time of $50 \mathrm{~s}$ were set to allow for accurate measurement of low viscosity fluids as recommended by ATS Rheosystems (Bordentown, NJ).

\section{Saliva-Beverage Interactions}

Approximately $25 \mathrm{~mL}$ of saliva from each of 3 subjects was collected at room temperature in less than $3 \mathrm{~h}$. The saliva was centrifuged at $12,000 \times g$ at $23^{\circ} \mathrm{C}$ for $20 \mathrm{~min}$ (Sorvall RC-5B Refrigerated Superspeed Centrifuge, DuPont Instruments, Wilmington, DE), and the supernatant was used immediately. Samples of protein beverages and saliva were combined in 1.5-mL microcentrifuge tubes in a 1:1 ratio (Gambuti et al., 2006). The tubes were capped, inverted once, vortexed briefly, and allowed to equilibrate at room temperature for $15 \mathrm{~min}$.

Turbidity (optical density at $400 \mathrm{~nm}$ ) was measured after 15 min using a Shimadzu UV160U spectrophotometer (Shimadzu Co., Kyoto, Japan) before and after centrifugation (Beckman Microfuge 11, Palo Alto, CA) at $13,500 \times g$ for $15 \mathrm{~min}$.

\section{Statistical Analysis}

All statistical analyses were performed using SAS version 9.1 (SAS Institute Inc., Cary, NC). Maximum sweet, sour, and bitter intensities were analyzed, and 4 parameters were extracted from the astringency TI curves: IMAX, time to maximum intensity, total duration of astringency, and area under the time-intensity curve. An ANOVA was generated using PROC GLM, and comparisons of means were made using Tukey's Studentized range honestly significant difference test.

\section{RESULTS}

The effects of beverage viscosity on astringency and basic tastes were investigated in the first experiment. Figure 1 shows the viscosities of the treatments. The lowest viscosity treatments $(<4 \mathrm{mPa} \cdot \mathrm{s})$ exhibited Newtonian behavior, whereas the others were slightly shear thinning, but with very little change in viscosity at shear rates $\geq 40 \mathrm{~s}^{-1}$. Sour and bitter intensities were similar across treatments with the exception of the control (no protein) having no sour taste (Table 1). Increasing viscosity from 1.6 to $7.7 \mathrm{mPa} \cdot \mathrm{s}$ did not result in significant differences in any astringency parameters (Figure 2 and Table 2).

In the second experiment, the effects of $4 \mathrm{pH}$ values $(2.6,3.0,3.4$, and 6.8$)$ on astringency and basic tastes of beverages were investigated. The $\mathrm{pH}$ values between 3.4 and 6.8 were not investigated because heating caused excessive aggregation in this $\mathrm{pH}$ range. For beverages with varying $\mathrm{pH}$, sourness significantly in-

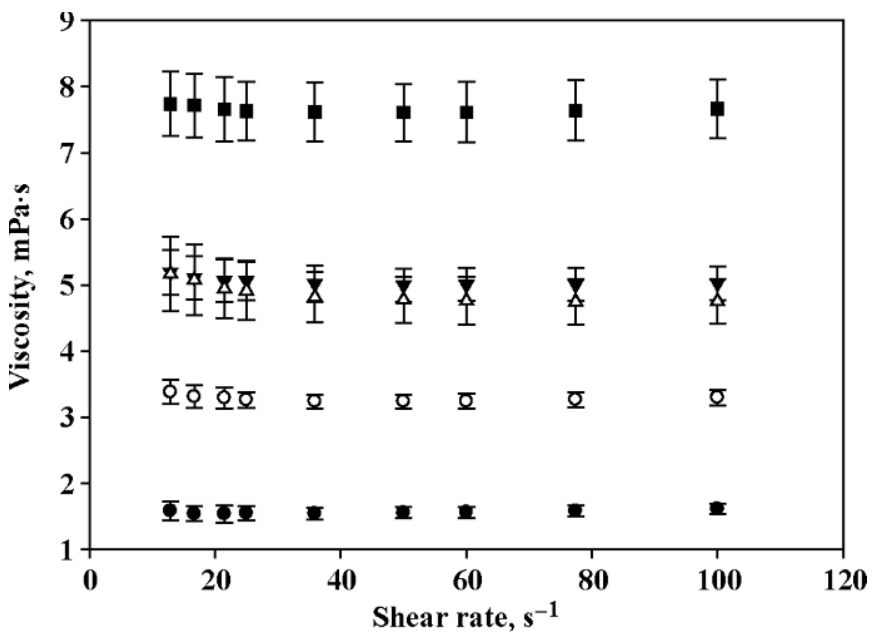

Figure 1. Viscosities of thickened model beverages at $20^{\circ} \mathrm{C}$. Values are the means of 4 replications. Error bars represent standard deviation. $=1.6 \mathrm{mPa} \cdot \mathrm{s}$, no thickener; $\bigcirc=3.3 \mathrm{mPa} \cdot \mathrm{s}, 10 \%$ maltodextrin; $\Delta=5.0 \mathrm{mPa} \cdot \mathrm{s}, 15 \%$ maltodextrin; $\Delta=4.9 \mathrm{mPa} \cdot \mathrm{s}, 0.27 \%$ methyl cellulose; and $\mathbf{\square}=7.7 \mathrm{mPa} \cdot \mathrm{s}, 20 \%$ maltodextrin.

creased as $\mathrm{pH}$ was lowered from 3.4 to 2.6 (Table 3). The neutral beverage exhibited no sourness and low astringency (IMAX = 1.2) compared with the acidic beverages. The phosphate buffer control exhibited very low astringency, but mean sourness was the same as the beverage at $\mathrm{pH}$ 3.0. This established that the panelists were not confusing sourness with astringency. Figure 3 shows the time-intensity behavior of astringency for treatments of varying $\mathrm{pH}$. Maximum astringency for the beverage at $\mathrm{pH} 2.6$ was significantly lower than the beverage at $\mathrm{pH} 3.4$ (Table 4).

Astringent compounds are known to interact with saliva proteins and cause an increase in optical density. Optical density was observed to be much greater in saliva-beverage mixtures when compared with the controls (Figure 4). Furthermore, the optical density of the saliva-beverage mixtures after centrifugation was down to approximate level of the controls. The controls

Table 1. Effects of viscosity on maximum sweet, sour, and bitter intensities $^{1}$

\begin{tabular}{lccc}
\hline Treatment & Sweet & Sour & Bitter \\
\hline Control & $8.6^{\mathrm{ab}}$ & $0.0^{\mathrm{b}}$ & $0.0^{\mathrm{b}}$ \\
$1.6 \mathrm{mPa} \cdot \mathrm{s}$ & $7.9^{\mathrm{b}}$ & $2.9^{\mathrm{a}}$ & $0.0^{\mathrm{b}}$ \\
$3.3 \mathrm{mPa} \cdot \mathrm{s}$ & $8.2^{\mathrm{ab}}$ & $2.6^{\mathrm{a}}$ & $0.0^{\mathrm{b}}$ \\
$5.0 \mathrm{mPa} \cdot \mathrm{s}$ & $8.5^{\mathrm{ab}}$ & $2.6^{\mathrm{a}}$ & $0.0^{\mathrm{b}}$ \\
$4.9 \mathrm{mPa} \cdot \mathrm{s}$ & $8.0^{\mathrm{b}}$ & $3.0^{\mathrm{a}}$ & $0.0^{\mathrm{b}}$ \\
$7.7 \mathrm{mPa} \cdot \mathrm{s}$ & $8.9^{\mathrm{a}}$ & $2.5^{\mathrm{a}}$ & $0.0^{\mathrm{b}}$ \\
\hline
\end{tabular}

${ }^{\mathrm{a}, \mathrm{b}}$ Significant differences within columns are denoted by different letters $(P<0.05)$.

${ }^{1}$ Values shown are on a 15 -point scale where $0=$ not detected and 15 = extremely high intensity. 


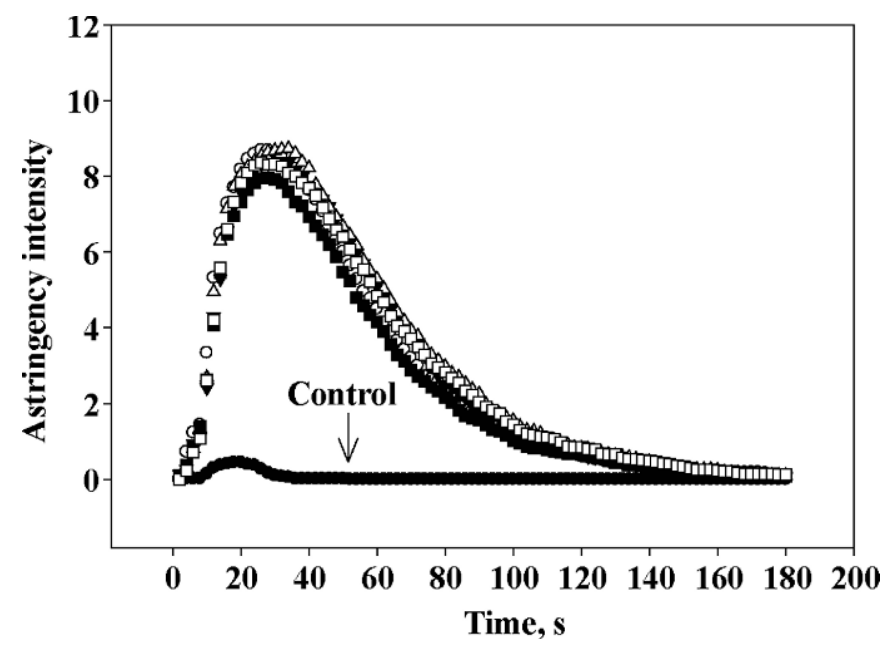

Figure 2. Astringency time intensity of thickened model beverages. Astringency intensity is measured on a 15-point scale. $=$ control; $\bigcirc=1.6 \mathrm{mPa} \cdot \mathrm{s} ; \boldsymbol{\nabla}=3.3 \mathrm{mPa} \cdot \mathrm{s} ; \triangle=5.0 \mathrm{mPa} \cdot \mathrm{s} ; \boldsymbol{\square}=4.9 \mathrm{mPa} \cdot \mathrm{s}$; and $\square=7.7 \mathrm{mPa} \cdot \mathrm{s}$.

were virtually unchanged. After centrifugation, pellets were observed in tubes containing saliva and beverage mixtures and not the controls (data not shown). The change in optical density was relatively small in the neutral $\mathrm{pH}$ beverage. The change in optical density after centrifugation was linearly related to sensorially determined astringency (Figure 5).

\section{DISCUSSION}

Previous research has shown that increasing viscosity by adding carboxymethyl cellulose decreases astringency due to grape seed tannins (Smith et al., 1996), or addition of methyl cellulose decreases astringency of alum (Smith and Noble, 1998). In both cases, astringency was reduced when viscosity was increased to 5 $\mathrm{mPa} \cdot \mathrm{s}$. In contrast, no effect of viscosity (1.6 to 7.7

Table 2. Effects of viscosity on time intensity analysis of astringency

\begin{tabular}{lcccr}
\hline & $\begin{array}{c}\text { Max } \\
\text { astringency } \\
\text { intensity }^{1}\end{array}$ & $\begin{array}{c}\text { Time } \\
\text { to max } \\
\text { astringency } \\
(\mathrm{s})\end{array}$ & $\begin{array}{c}\text { Duration } \\
(\mathrm{s})\end{array}$ & $\begin{array}{c}\text { Area } \\
\text { under } \\
\text { curve }\end{array}$ \\
\hline Control & $0.5^{\mathrm{b}}$ & $10.4^{\mathrm{b}}$ & $13.4^{\mathrm{b}}$ & $49^{\mathrm{b}}$ \\
$1.6 \mathrm{mPa} \cdot \mathrm{s}$ & $9.1^{\mathrm{a}}$ & $25.5^{\mathrm{a}}$ & $113.0^{\mathrm{a}}$ & $3,325^{\mathrm{a}}$ \\
$3.3 \mathrm{mPa} \cdot \mathrm{s}$ & $8.7^{\mathrm{a}}$ & $27.9^{\mathrm{a}}$ & $119.8^{\mathrm{a}}$ & $3,376^{\mathrm{a}}$ \\
$5.0 \mathrm{mPa} \cdot \mathrm{s}$ & $9.1^{\mathrm{a}}$ & $27.2^{\mathrm{a}}$ & $119.7^{\mathrm{a}}$ & $3,616^{\mathrm{a}}$ \\
$4.9 \mathrm{mPa} \cdot \mathrm{s}$ & $8.3^{\mathrm{a}}$ & $26.3^{\mathrm{a}}$ & $110.3^{\mathrm{a}}$ & $3,016^{\mathrm{a}}$ \\
$7.7 \mathrm{mPa} \cdot \mathrm{s}$ & $8.8^{\mathrm{a}}$ & $26.3^{\mathrm{a}}$ & $116.0^{\mathrm{a}}$ & $3,432^{\mathrm{a}}$ \\
\hline
\end{tabular}

${ }^{\mathrm{a}, \mathrm{b}}$ Significant differences within columns are denoted by different letters $(P<0.05)$.

${ }^{1}$ Maximum astringency adjusted from 100-point scale to 15-point scale.
Table 3. Effects of $\mathrm{pH}$ on maximum sweet, sour, and bitter intensities $^{1}$

\begin{tabular}{lccc}
\hline Treatment & Sweet & Sour & Bitter \\
\hline pH 2.6 & $6.9^{\mathrm{bc}}$ & $6.1^{\mathrm{a}}$ & $0.0^{\mathrm{b}}$ \\
pH 3.0 & $8.2^{\mathrm{a}}$ & $3.9^{\mathrm{b}}$ & $0.0^{\mathrm{b}}$ \\
pH 3.4 & $7.9^{\mathrm{ab}}$ & $2.8^{\mathrm{c}}$ & $0.0^{\mathrm{b}}$ \\
pH 6.8 & $8.2^{\mathrm{a}}$ & $0.0^{\mathrm{d}}$ & $0.0^{\mathrm{b}}$ \\
pH 3.4 buffer & $6.6^{\mathrm{c}}$ & $4.2^{\mathrm{b}}$ & $0.0^{\mathrm{b}}$ \\
\hline
\end{tabular}

${ }^{\mathrm{a}-\mathrm{c}}$ Significant differences within columns are denoted by different letters $(P<0.05)$.

${ }^{1}$ Values shown are on a 15 -point scale where $0=$ not detected and 15 = extremely high intensity.

$\mathrm{mPa} \cdot \mathrm{s})$ on protein-based astringency was observed. There are several possible reasons for these differences. First, it is possible that protein-based astringency requires even higher viscosity to alter the tactile sensation. The maximum viscosity used in this study was similar to maximum viscosities seen in commercial beverages (unpublished data); therefore, higher viscosities, if effective, may be problematic from a sensory acceptance perspective. It is also possible that the polysaccharides used in previous investigations (Smith et al., 1996; Smith and Noble, 1998) interacted directly with the astringent compounds and thereby decreased astringency. Two different thickeners were used in this investigation to rule out interactions that might occur between the thickener used to increase viscosity and whey proteins. Although some differences in sweetness $(P<0.05)$ were observed among samples (Table 1$)$, there was no overall trend. The control sample was judged to be as sweet as other samples and was not judged to be sour or astringent, as would be expected due to the

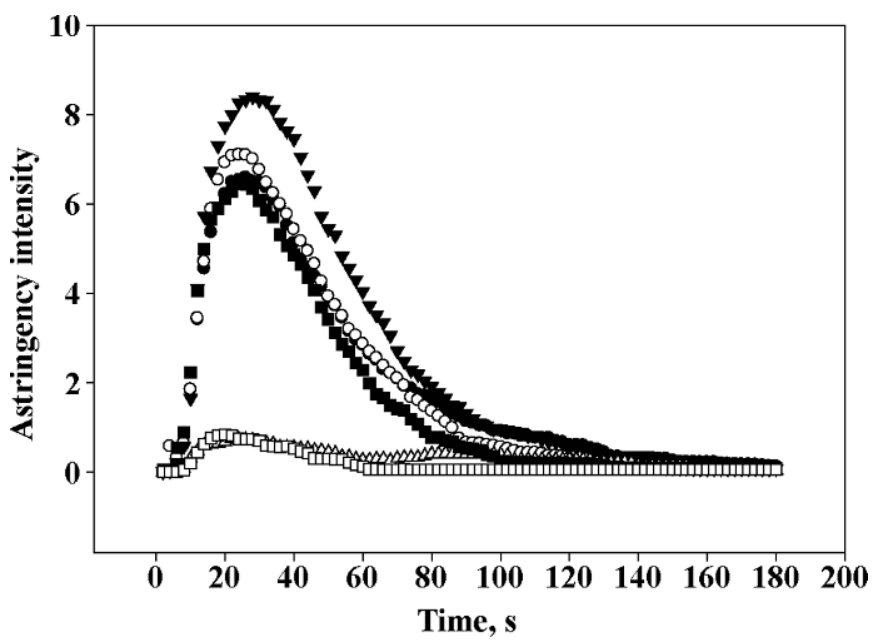

Figure 3. Astringency time intensity of model beverages of varying $\mathrm{pH}$. Astringency intensity is measured on a 15 -point scale. $\boldsymbol{\theta}=\mathrm{pH}$

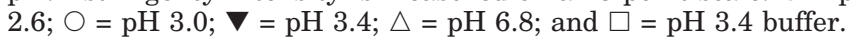


Table 4. Effects of $\mathrm{pH}$ on time intensity analysis of astringency

\begin{tabular}{lcccc}
\hline & $\begin{array}{c}\text { Max } \\
\text { astringency } \\
\text { intensity }\end{array}$ & $\begin{array}{c}\text { Time } \\
\text { to max } \\
\text { astringency } \\
\text { Treatment }\end{array}$ & $\begin{array}{c}\text { Duration } \\
(\mathrm{s})\end{array}$ & $\begin{array}{c}\text { Area } \\
\text { under } \\
\text { curve }\end{array}$ \\
\hline pH 2.6 & $7.1^{\mathrm{b}}$ & $24.3^{\mathrm{ab}}$ & $91.2^{\mathrm{a}}$ & $2,349^{\mathrm{ab}}$ \\
pH 3.0 & $7.8^{\mathrm{ab}}$ & $24.8^{\mathrm{ab}}$ & $87.2^{\mathrm{a}}$ & $2,270^{\mathrm{b}}$ \\
pH 3.4 & $8.8^{\mathrm{a}}$ & $26.2^{\mathrm{a}}$ & $97.1^{\mathrm{a}}$ & $2,956^{\mathrm{a}}$ \\
pH 6.8 & $1.2^{\mathrm{c}}$ & $16.2^{\mathrm{bc}}$ & $55.6^{\mathrm{b}}$ & $375^{\mathrm{c}}$ \\
pH 3.4 buffer & $1.0^{\mathrm{c}}$ & $12.0^{\mathrm{c}}$ & $43.3^{\mathrm{b}}$ & $218^{\mathrm{c}}$ \\
\hline
\end{tabular}

${ }^{\mathrm{a}-\mathrm{c}}$ Significant differences within columns are denoted by different letters $(P<0.05)$.

${ }^{1}$ Maximum astringency adjusted from 100 -point scale to 15 -point scale.

absence of protein or phosphoric acid. Because the viscosity of the control would be similar to that of the thinnest sample ( 1 to $1.6 \mathrm{mPa} \cdot \mathrm{s})$, it served as a lowviscosity comparison.

In model beverages with varying $\mathrm{pH}$, sourness increased significantly as $\mathrm{pH}$ was lowered. This is expected as lower $\mathrm{pH}$ required more acid, and sourness is related to the total concentration of hydrogen ions and protonated acids (da Conceicao Neta et al., 2007). Because an increase in sourness can cause a decrease in sweetness perception (Keast and Breslin, 2002), the slight decrease in sweetness observed between $\mathrm{pH} 3.0$ and 2.6 may be attributed to this effect (Table 3). Acids are known to cause astringency (Lawless et al., 1996); therefore, a $\mathrm{pH} 3.4$ phosphate buffer was used as a control to see the effect of the acidulant at a buffering capacity similar to the whey protein solution because

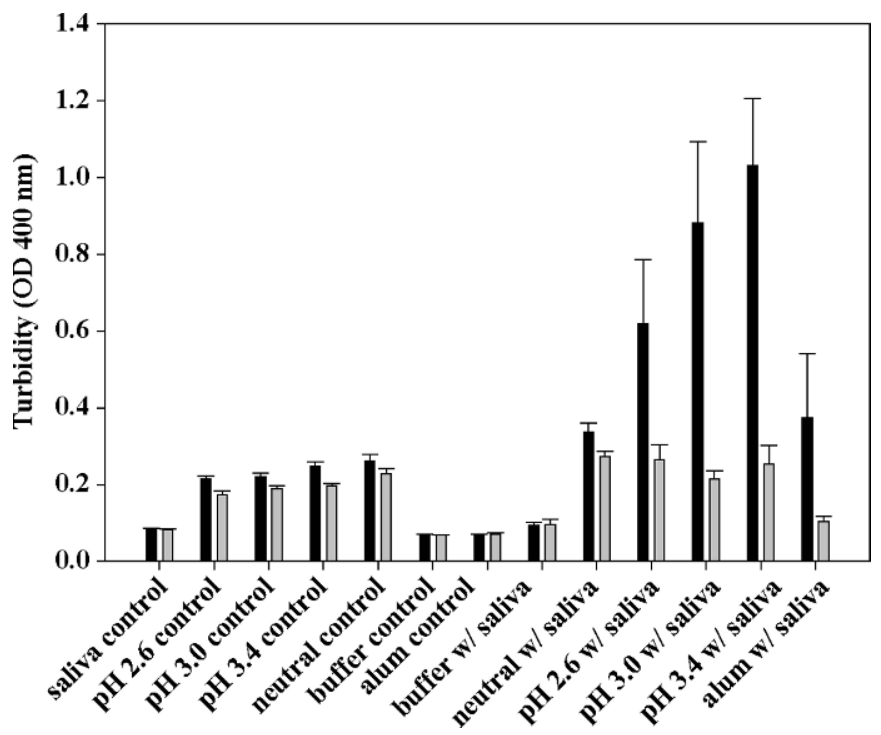

Figure 4. Optical density of saliva, model protein beverages, and alum $(0.8 \mathrm{~g} / \mathrm{L})$ mixtures before (black bars) and after centrifugation (gray bars).

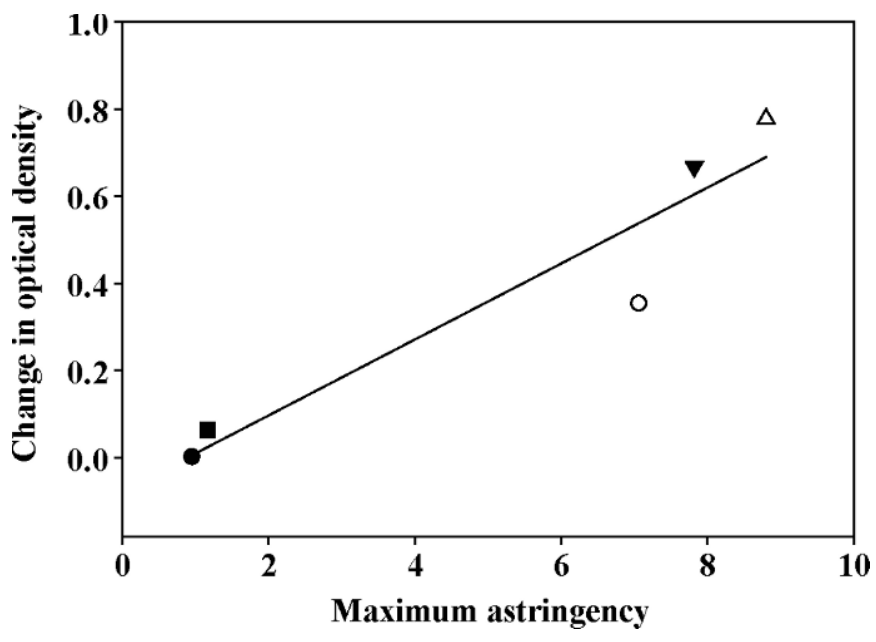

Figure 5. Relationship between change in optical density before and after centrifugation and maximum astringency $\left(r^{2}=0.90\right)$. Astringency intensity is measured on a 15 -point scale. $0=\mathrm{pH} 3.4$ buffer; $\mathrm{O}=\mathrm{pH} 2.6 ; \boldsymbol{\nabla}=\mathrm{pH} 3.0 ; \Delta=\mathrm{pH} 3.4 ;$ and $\boldsymbol{\square}=\mathrm{pH} 6.8$.

buffering capacity is essential to the mechanism proposed by Sano et al. (2005). The phosphate buffer control was perceived as being more sour and less sweet than the $\mathrm{pH} 3.4$ whey protein beverage (Table 3); however, it had very low astringency (Table 4). Similarly, a $\mathrm{pH} 3.4,5 \mathrm{~m} M$ sodium phosphate buffer was judged as not astringent (Sano et al., 2005). Because $\mathrm{NaCl}$ has been shown to decrease the astringency of alum and tannic acid (Brannan et al., 2001b), it seems logical that the sodium in the buffers could have the same effect. That would explain the lower level of astringency observed for phosphate buffers in this investigation and that of Sano et al. (2005).

The acidic beverages ( $\mathrm{pH} 3.4$ to 2.6) were more astringent than the $\mathrm{pH} 6.8$ beverage, as seen by greater maximum intensity and duration of astringency (Table 4). However, a decrease in astringency was observed between $\mathrm{pH} 3.4$ and 2.6 (Table 4) that coincided with an increase in sourness (Table 3). The effect of acids on astringency depends on the compound causing astringency. Adding citric acid (7.08 $\mathrm{mM})$ increases astringency of phenolic compounds but decreases astringency of alum (Peleg et al., 1998). Increasing concentration of citric acid (3.9 to $7.8 \mathrm{mM}$ ) or $\mathrm{HCl}(4.7$ to $9.4 \mathrm{mM}$ ) causes an increase in sourness but no change in alum astringency (Peleg et al., 1998). It appears that the effect of $\mathrm{pH}$ on astringency will depend on the precise mechanism causing astringency.

When saliva was mixed with beverages, the increase in turbidity correlated with level of astringency (Figure 5 ). This is comparable to an increase in tannic acid concentration causing an increase in saliva turbidity and astringency (Lawless et al., 1994; Horne et al., 
2002). Or more similarly, a decrease in $\mathrm{pH}$ (5.2 to 3.9) of $1 \%$ chitosan solutions coinciding with an increase in turbidity of saliva and astringency (Rodriguez et al., 2003). Although the correlation between turbidity and astringency seen in Figure 5 is encouraging in defining a whey protein astringency mechanism, it should be interpreted with caution. Turbidity (light scattering) measured as a decrease in light transmitted at a given wavelength (optical density), or light scattered at a $90^{\circ}$ angle, is a function of the size, shape, and concentration of particles, with variations in each causing a change in turbidity. A true understanding of the aggregation process will be obtained by using multi-angle light scattering techniques that allow for separation of molar mass and shape factors.

The formation of aggregates, as indicated by an increased turbidity of whey protein-saliva mixtures, can be explained based on 2 possible mechanisms. First, as proposed by Sano et al. (2005), whey proteins at acidic $\mathrm{pH}$ when mixed with neutral $\mathrm{pH}$ saliva could result in a beverage-saliva solution at a $\mathrm{pH}$ close to the $\mathrm{pI}$ of whey proteins, favoring aggregation as observed by an increase in turbidity. In this case, the whey protein aggregates are the cause of astringency. This mechanism could explain the data in Figure 5. Alternatively, it could be due to interactions between the positively charged whey proteins $(\mathrm{pH}<\mathrm{pI})$ and negatively charged saliva proteins. If salivary proteins have isoelectric points below the isoelectric points of whey proteins, there will be a $\mathrm{pH}$ range that results in a net electrostatic attraction causing aggregation. Guo et al. (2006) sequenced 5,338 distinct peptides, representing 1,381 distinct proteins, from human saliva. Approximately 3,400 of the 5,338 peptides where identified as having mean isoelectric points below 5.0. These proteins are likely to be involved in interactions with whey proteins in acidic beverages due to general electrostatic charge attraction. At $\mathrm{pH}$ 6.8, the salivary and whey proteins are highly negative and less likely to aggregate. In contrast, at $\mathrm{pH} 3.4$, the net attraction between salivary and whey proteins appears to be the strongest, resulting in the highest level of astringency (Table 4). This is similar to the effect of $\mathrm{pH}$ on chitosan astringency (Rodriguez et al., 2003). As pH is lowered from 3.4 to 2.6, the salivary and whey proteins become more positively charged, decreasing protein-protein interactions and astringency. Sano et al. (2005) showed that astringency was also related to $\mathrm{pH} 3.5$ whey proteins binding a negatively charged electrode, supporting the possibility of interacting with saliva proteins.

\section{CONCLUSIONS}

Astringency of whey protein solutions is not decreased by increasing viscosity over the range of 1.6 to
$7.7 \mathrm{mPa} \cdot \mathrm{s}$. High levels of astringency are associated with increased turbidity of protein saliva mixtures. We are proposing that the turbidity could be related to negatively charged salivary proteins interacting with positively charged whey proteins to form aggregates, similar to polyphenolic compounds and saliva proteins interacting to cause astringency. Whereas this mechanism is generally similar to astringency caused by polyphenols and alum, the inability of increased viscosity to alter protein-based astringency suggests differences in the mechanisms.

\section{ACKNOWLEDGMENTS}

Paper no. FSR-08-04 of the Journal Series of the Department of Food Science, North Carolina State University, Raleigh, NC 27695-7624. Support from the North Carolina Agricultural Research Service (Raleigh, NC), Dairy Management Inc. (Rosemont, IL), and the Southeast Dairy Foods Research Center (Raleigh, NC), and gifts from Davisco Foods International (Le Sueur, $\mathrm{MN}$ ) and Glanbia Nutritionals (Monroe, WI) are gratefully acknowledged. This investigation is in collaboration with Kimberlee Burrington of the Dairy Ingredient Applications Center at the Wisconsin Center for Dairy Research (Madison, WI). The use of trade names in this publication does not imply endorsement by the North Carolina Agricultural Research Service of the products named nor criticism of similar ones not mentioned.

\section{REFERENCES}

ASTM. 1989. Standard definitions of terms relating to sensory evaluation of materials and products. American Society for Testing and Materials, Philadelphia, PA.

Brannan, G. D., C. S. Setser, and K. E. Kemp. 2001a. Effectiveness of rinses in alleviating bitterness and astringency residuals in model solutions. J. Sens. Stud. 16:261-275.

Brannan, G. D., C. S. Setser, and K. E. Kemp. 2001b. Interaction of astringency and taste characteristics. J. Sens. Stud. 16:179-197.

Colonna, A. E., D. O. Adams, and A. C. Noble. 2004. Comparison of procedures for reducing astringency carry-over effects in evaluation of red wines. Aust. J. Grape Wine Res. 10:26-31.

Da Conceicao Neta, E. R., S. D. Johanningsmeier, M. A. Drake, and R. F. McFeeters. 2007. A chemical basis for sour taste perception of acid solutions and fresh-pack dill pickles. J. Food Sci. 72:S352-S359.

Gambuti, A., A. Rinaldi, R. Pessina, and L. Moio. 2006. Evaluation of aglianico grape skin and seed polyphenol astringency by SDSPAGE electrophoresis of salivary proteins after the binding reaction. Food Chem. 97:614-620.

Green, B. G. 1993. Oral astringency: A tactile component of flavor. Acta Psychol. (Amst.) 84:119-125.

Grenby, T. H. 1991. Intense sweeteners for the food industry: An overview. Trends Food Sci. Technol. 2:2-6.

Guinard, J. X., R. M. Pangborn, and M. J. Lewis. 1986. The timecourse of astringency in wine upon repeated ingestions. Am. J. Enol. Vitic. 37:184-189.

Guo, T., P. A. Rudnick, W. Wang, C. S. Lee, D. L. DeVoe, and B. M. Balgley. 2006. Characterization of the human salivary proteome by capillary isoelectric focusing/nanoreversed-phase liquid chro- 
matography coupled with ESI-tandem MS. J. Proteome Res. 5:1469-1478.

Horne, J., J. Hayes, and H. T. Lawless. 2002. Turbidity as a measure of salivary protein reactions with astringent substances. Chem. Senses 27:653-659.

Jobstl, E., J. O'Connell, J. Patrick, J. P. A. Fairclough, and M. P. Williamson. 2004. Molecular model for astringency produced by polyphenol/protein interactions. Biomacromolecules 5:942-949.

Keast, R. S. J., and P. A. S. Breslin. 2002. An overview of binary taste-taste interactions. Food Qual. Prefer. 14:111-124.

Lawless, H. T., C. J. Corrigan Thomas, and C. B. Lee. 1994. Interactions of astringent substances. Chem. Senses 19:141-154.

Lawless, H. T., and H. Heymann. 1998. Sensory evaluation of food: Principles and practices. Chapman \& Hall, New York, NY.

Lawless, H. T., J. Horne, and P. Giasi. 1996. Astringency of organic acids is related to $\mathrm{pH}$. Chem. Senses 21:397-403.

Lee, C. B., and H. T. Lawless. 1991. Time-course of astringent sensations. Chem. Senses 16:225-238.

Lesschaeve, I., and A. C. Noble. 2005. Polyphenols: Factors influencing their sensory properties and their effects on food and beverage preferences. Am. J. Clin. Nutr. 81:330S-335S.

Meilgaard, M., G. V. Civille, and B. T. Carr. 1999a. Sensory Evaluation Techniques. 3rd ed. CRC Press Inc., Boca Raton, FL.

Meilgaard, M. M., G. V. Civille, and T. Carr. 1999b. Descriptive analysis techniques. CRC Press, Boca Raton, FL.

Peleg, H., K. K. Bodine, and A. C. Noble. 1998. The influence of acid on astringency of alum and phenolic compounds. Chem. Senses 23:371-378.
Pelegrine, D. H. G., and C. A. Gasparetto. 2005. Whey proteins solubility as function of temperature and $\mathrm{pH}$. Lebensm. Wiss. Technol. 38:77-80.

Phillips, L. G., D. M. Whitehead, and J. E. Kinsella. 1994. Structurefunction properties of food proteins. Academic Press, San Diego, CA.

Rodriguez, M. S., L. A. Albertengo, I. Vitale, and E. Agullo. 2003. Relationship between astringency and chitosan-saliva solutions turbidity at different pH. J. Food Sci. 68:665-667.

Sano, H., T. Egashira, Y. Kinekawa, and N. Kitabatake. 2005. Astringency of bovine milk whey protein. J. Dairy Sci. 88:2312-2317.

Scharbert, S., N. Holzmann, and T. Hofmann. 2004. Identification of the astringent taste compounds in black tea infusions by combining instrumental analysis and human bioresponse. J. Agric. Food Chem. 52:3498-3508.

Schlich, P. 1993. Uses of change-over designs and repeated measurements in sensory and consumer studies. Food Qual. Prefer. 4:223-235.

Smith, A. K., H. June, and A. C. Noble. 1996. Effects of viscosity on the bitterness and astringency of grape seed tannin. Food Qual. Prefer. 7:161-166.

Smith, A. K., and A. C. Noble. 1998. Effects of increased viscosity on the sourness and astringency of aluminum sulfate and citric acid. Food Qual. Prefer. 9:139-144.

Vivas, N., and Y. Glories. 1996. Role of oak wood ellagitannins in the oxidation process of red wines during aging. Am. J. Enol. Vitic. 47:103-107. 